\title{
ПОНЯТИЕ ДОЛЖНОСТНОГО ЛИЦА В АДМИНИСТРАТИВНОМ ЗАКОНОДАТЕЛЬСТВЕ РОССИИ
}

Аннотация: Предметом исследования является понятие должностного лица на основании Кодекса Российской Федерации об административных правонарушениях и его характеристика. Дается сравнение понятий "должностного лица" предусмотренных Уголовным кодексом Российской Федерации и Кодексом Российской Федерации об административных правонарушениях. А также анализируются разъяснения пленума Верховного суда Российской Федерации по тем, критериям которые позволяют отнести лицо совершившее преступление к должностному лицу и его отличия от иных лиц занимающих должности в государственных органах власти. Методами исследования явились диалектический и юридический способы анализа, проведено сравнение уголовного и административного законодательства, эмпирический синтез понятий должностного лица на основании судебной практики. Научной новизной исследования является частное мнение по установлению критериев позволяющих определить понятие "должностного лица" по административному законодательству. В частности предлагается не связывать понятие должностного лица предусмотренного в статье 2.4 КоАП РФ с совершенным правонарушением, так как это создает определенные проблемы в квалификации деяний совершенных данной категории лии, а также привлечение их к административной ответственности.

Ключевые слова: преступление, правонарушение, функции, полномочия, власть, государство, должность, лицо, определение, вина.

Review: The subject of the research is the concept of public individual on the base of the Code of Administrative Offences of the Russian Federation and its description. The author compares the notions of "public individual" provided by the Criminal Code of the Russian Federation and the Code of Administrative Offences. The author analyzes the explanations of the plenum of the Supreme Court of the Russian Federation related to the criteria which allow rating a person who has committed a crime as a public individual and this person's difference from other state public officers. The author uses the dialectic and juridical methods of analysis, compares criminal and administrative legislation, carries out the empirical synthesis of public individual definitions on the base of court practice. The scientific novelty of the research lies in the private opinion about the criteria defining the concept of "public individual" on the base of administrative legislation. Particularly, the author offers not to associate the notion of public individual as provided in the article 2.4 of the Code of Administrative Offences of the Russian Federation with the offense committed, since it causes particular problems with the qualification of acts committed by this category of persons and the institution of administrative proceedings against them.

Keywords: crime, offense, functions, competences, authority, state, position, person, definition, guilt.

$\mathrm{C}$ оразмерность наказания, назначаемого за совершение правонарушения, являлось и является предметом многих исследований, в том, числе связанных со свойствами субъектов правонарушений. Законодатель на современном этапе становления российского общества, уделяя особое внимание правовому воспитанию граждан создает и совершенствует систему ответственности за правонарушение, где упор делает на субъективный состав правонарушений, в частности выделяя граждан, должностных и юридических лиц.

Так, некоторые нормативно-правовые акты имеют категории преступлений. Например, в Уголовном кодексе Российской Федерации (далее - УК 
РФ) статья 15 разграничивает преступления в зависимости от характера и степени общественной опасности деяния, на преступления небольшой тяжести, преступления средней тяжести, тяжкие преступления и особо тяжкие преступления ${ }^{1}$. В административном законодательстве данного разграничения на категории не делается, однако устанавливается соразмерная ответственность для физических лиц, должностных и юридических лиц.

Кодекс Российской Федерации об административных правонарушениях устанавливает размер наказания в зависимости от субъекта административного правонарушения, предусмотрев, что физическое лицо несет менее строгое наказание чем должностное, а юридическое лицо несет более строгое наказание по сравнению с остальными субъектами ${ }^{2}$.

По своему социальному назначению наказания должны иметь воспитательный, профилактический, превентивный характер. Любая мера ответственности должна иметь целью исправление лиц, нарушивших закон. Указанному обстоятельству должна способствовать неотвратимость и соразмерность наказания за совершенное правонарушение исходя из степени вины и причиненного ущерба 3 .

В российском праве определение понятия должностного лица базируется на синтезе нескольких понятийных категорий, предусмотренных уголовным и административным законодательством.

Так, Верховный Суд Российской Федерации, разъясняет, что при разрешении вопроса о том, совершено ли преступление должностным лицом, лицом, занимающим государственную должность Российской Федерации,либо государственнуюдолжность субъекта Российской Федерации, иностранным должностным лицом, должностным лицом публичной международной организации (далее должностное лицо), а равно лицом, выполняющим управленческие функции в коммерческой или иной организации, судам следует руководствоваться примечаниями 1, 2 и 3 к статье 285, примечанием 2 к

\footnotetext{
1 См.: Уголовный кодекс Российской Федерации от 13 июня 1996 г. № 63-Ф3 (в ред. Федерального закона от 4 июня 2014 г. № 142-Ф3) // Собрание законодательства Российской Федерации. 1996. № 25. Ст. 2954.

2 См.: Кодекс Российской Федерации об административных правонарушениях от 30 декабря 2001 г. № 195-ФЗ (в ред. Федерального закона от 4 июня 2014 г. № 143-Ф3) // Собрание законодательства Российской Федерации. 2002. № 1 (ч. І). Ст. 1.

3 См.: Паньшин Д.Л., Дресвянникова Е.А. Сроки и порядок исполнения постановлений по делам об административных правонарушениях о штрафах // Административное и муниципальное право. - 2014. - №8. - 797 - 800.
}

статье 290, примечанием 1 к статье 201 Уголовного кодекса Российской Федерации (далее УК РФ) ${ }^{4}$, а также учитывая при этом соответствующие разъяснения, содержащиеся в постановлении Пленума Верховного Суда Российской Федерации от 16 октября 2009 года № 19 «0 судебной практике по делам о злоупотреблении должностными полномочиями и о превышении должностных полномочий» 5 .

Примечаниями 1, 2 и 3 к статье 285 УК РФ, предусматривается, что это лица, постоянно, временно или по специальному полномочию осуществляющие функции представителя власти либо выполняющие организационно-распорядительные, административно-хозяйственные функции в государственных органах, органах местного самоуправления, государственных и муниципальных учреждениях, государственных корпорациях, а также в Вооруженных Силах Российской Федерации, других войсках и воинских формированиях Российской Федерации. Под лицами, занимающими государственные должности Российской Федерации, понимаются лица, занимающие должности, устанавливаемые Конституцией Российской Федерации, федеральными конституционными законами и федеральными законами для непосредственного исполнения полномочий государственных органов. Под лицами, занимающими государственные должности субъектов Российской Федерации, понимаются лица, занимающие должности, устанавливаемые конституциями или уставами субъектов Российской Федерации для непосредственного исполнения полномочий государственных органов. Государственные служащие и муниципальные служащие, не относящиеся к числу должностных лиц, несут уголовную ответственность по статьям настоящей главы в случаях, специально предусмотренных соответствующими статьями ${ }^{6}$.

\footnotetext{
4 Постановление Пленума Верховного Суда Российской Федерации от 09 июля 2013 г. № 24 «О судебной практике по делам о взяточничестве и об иных коррупционных преступлениях». Официальный сайт Верховного Суда Российской Федерации: http://www.supcourt.ru/second.php (Дата обращения 15 октября 2014 г.).

5 См.: Постановление Пленума Верховного Суда Российской Федерации от 16 октября 2009 года № 19 «О судебной практике по делам о злоупотреблении должностными полномочиями и о превышении должностных полномочий». Официальный сайт Верховного Суда Российской Федерации: http://www.supcourt. ru/second.php (Дата обращения 15 октября 2014 г.).

6 Уголовный кодекс Российской Федерации от 13 июня 1996 г. № 63-Ф3 (ред. от 21.07.2014 г.) (с изм. и доп. вступ. в силу 04.08.2014 г.) // Собрание законодательства РФ. 1996. - № 25. - Ст. 2954.
} 
Примечанием 2 к статье 290 УК РФ предусматривается, что под иностранным должностным лицом понимается любое назначаемое или избираемое лицо, занимающее какую-либо должность в законодательном, исполнительном, административном или судебном органе иностранного государства, и любое лицо, выполняющее какую-либо публичную функцию для иностранного государства, в том числе для публичного ведомства или публичного предприятия; под должностным лицом публичной международной организации понимается международный гражданский служащий или любое лицо, которое уполномочено такой организацией действовать от ее имени.

Примечанием 1 к статье 201 УК РФ, устанавливается, что выполняющим управленческие функции в коммерческой или иной организации, а также в некоммерческой организации, не являющейся государственным органом, органом местного самоуправления, государственным или муниципальным учреждением, признается лицо, выполняющее функции единоличного исполнительного органа, члена совета директоров или иного коллегиального исполнительного органа, а также лицо, постоянно, временно либо по специальному полномочию выполняющее организационно-распорядительные или административнохозяйственные функции в этих организациях.

Таким образом, уголовное законодательство с понятием должностного лица связывает его должность и возложенные на него обязанности, связанные с занимаемым положением на предприятии, учреждении или организации, а также в государственных органах власти.

Тогда как, по смыслу административного законодательства статус должностного лица вопервых, распространяется на физических лиц, наделенных организационно-распорядительными или административно-хозяйственными функциями в государственных органах, органах местного самоуправления, государственных и муниципальных организациях, а также в Bооруженных Силах Российской Федерации, других войсках и воинских формированиях Российской Федерации, а во-вторых на лиц, совершивших определенный круг правонарушений (статья 2.4 КоАП РФ), занимая определенные должности в юридическом лице, независимо от формы собственности и подчиненности, а также на индивидуальных предпринимателей.

Хотелось бы обратить внимание, что должностным лицом станет тот субъект административных правонарушений, который совершит одно или несколько административных правонарушений.

В тоже время, анализируя часть 2 статьи 1.5 КоАП РФ, автор статьи приходит к выводу, что лицо признается совершившим правонарушение только на основании вступившего в законную силу постановления. Так, закреплённый принцип презумпции невиновности (статья 1.5 КоАП РФ), предусматривает, что лицо, в отношении которого ведется производство по делу об административном правонарушении, считается невиновным, пока его вина не будет доказана в порядке, предусмотренном КоАП РФ, и установлена вступившим в законную силу постановлением судьи, органа, должностного лица, рассмотревших дело.

Следовательно, для того, чтобы установить, что лицо совершило административное правонарушение необходимо наличие следующих обязательных условий: в отношении лица должно вестись дело об административном правонарушении; его вина должна быть доказана в установленном КоАП РФ порядке; наличие вступившего в законную силу постановления судьи, органа, должностного лица рассмотревших дело.

Данные выводы можно сделать проанализировав понятие административного правонарушения (статья 2.1 КоАП РФ), как противоправного, виновного действия (бездействия) физического лица, за которое КоАП РФ или законами субъектов Российской Федерации об административных правонарушениях установлена административная ответственность.

Лицо совершившее правонарушение признается им только тогда, когда его вина будет установлена вступившим в законную силу постановлением по делу об административном правонарушении, то есть доказана его вина в совершении административного правонарушения.

Таким образом, автор приходит к выводу, что должностное лицо - это физическое лицо, совершившее противоправное, виновное действие (бездействие) за которое КоАП РФ или законами субъектов Российской Федерации об административных правонарушениях установлена административная ответственность. При этом необходимо иметь ввиду, что наличие вступившего в законную силу постановления обязательно. Иначе нельзя будет говорить об установлении и доказанности вины в совершении административного правонарушения.

В правоприменительной практике не редко встает вопрос о привлечении должностных лиц 
к административной ответственности. Если мы говорим о должностных лицах, как о лицах, наделенных функциями представителя власти в государственных органах, органах местного самоуправления, государственных и муниципальных организациях, то в квалификации деяния и в порядке привлечения к ответственности проблем не возникает. В большинстве случаев правоприменители сталкиваются с другой категорией должностных лиц, которых законодатель определил, как лиц, совершивших правонарушения, предусмотренных отдельными статьями КоАП РФ.

С выше указанным утверждением законодателя в статье 2.4 КоАП РФ, на наш взгляд, нельзя согласиться, поскольку, поставив в зависимость от совершенного правонарушения признание лица, как «должностного», позволит данному лицу избежать административной ответственности. Поскольку на момент возбуждения дела об административном правонарушении и при сборе доказательств его вины, лицо еще не является должностным, что влияет на правильную квалификацию и степень административной ответственности.
С правоприменительной точки зрения это выглядит так. В соответствии со статьей 28.2 КоАП РФ в протоколе об административном правонарушении указывается событие, отражающее объективную сторону правонарушения, предусмотренного диспозицией статьи. Например, «являясь должностным лицом, ответственным за техническое состояние и эксплуатацию транспортных средств, допустил к управлению транспортным средством водителя находящегося в состоянии опьянения» (статья 12.32 КоАП РФ). В тоже время анализируя статью 2.4 КоАП РФ на стадии возбуждения дела об административном правонарушении и при проведении рассмотрения нельзя утверждать, что это лицо, подозреваемое в совершении правонарушения не является «должностным», поскольку отсутствуют доказательства его вины подтвержденных вступившим в законную силу постановлением.

В этой связи автором статьи предлагается внести изменения в примечание к статье 2.4 КоАП РФ исключив из него указание, как на признак должностного лица, факта «совершения административного правонарушения».

\section{Библиография:}

1. Паньшин Д.Л., Дресвянникова Е.А. Сроки и порядок исполнения постановлений по делам об административных правонарушениях о штрафах // Административное и муниципальное право. - 2014.-№8. - 797 - 800.

2. Винокуров А.Ю. Контроль за соответствием расходов лиц, замещающих государственные должности, и иных лиц их доходам как самостоятельная функция прокуратуры // Административное и муниципальное право.-2013.2.-C. 108-112. DOI: 10.7256/1999-2807.2013.02.2.

3. Уголовный кодекс Российской Федерации от 13 июня 1996 г. № 63-ФЗ (ред. от 21.07.2014 г.) (с изм. и доп. вступ. в силу 04.08.2014 г.) // Собрание законодательства РФ. - 1996. - № 25. - Ст. 2954.

4. Постановление Пленума Верховного Суда Российской Федерации от 09 июля 2013 г. № 24 «0 судебной практике по делам о взяточничестве и об иных коррупционных преступлениях». Официальный сайт Верховного Суда Российской Федерации: http://www.supcourt.ru/second.php (Дата обращения 15 октября 2014 г.).

5. Постановление Пленума Верховного Суда Российской Федерации от 16 октября 2009 года № 19 «0 судебной практике по делам о злоупотреблении должностными полномочиями и о превышении должностных полномочий». Официальный сайт Верховного Суда Российской Федерации: http://www.supcourt.ru/second.php (Дата обращения 15 октября 2014 г.).

6. Кодекс Российской Федерации об административных правонарушениях от 30 декабря 2001 г. № 195-ФЗ (в ред. Федерального закона от 4 июня 2014 г. № 143-Ф3) // Собрание законодательства Российской Федерации. 2002. № 1 (ч. І). Ст. 1

7. Черногоров Д.А. Истоки формирования законодательства и правовой доктрины о должностных лицах // Административное и муниципальное право.-2011.-11.-С. 88-91.

8. Черногоров Д.А. Публичная служба и должностное лицо // Административное и муниципальное право.-2014.8.-C. 749-755. DOI: 10.7256/1999-2807.2014.8.12398.

9. Чепус А.В. Современное состояние российского законодательства о парламентской ответственности в РФ // Право и политика. - 2013. - 12. - С. 1665 - 1671. DOI: 10.7256/1811-9018.2013.12.10214.

10. Черногоров Д.А. Публичная служба и должностное лицо // Административное и муниципальное право. - 2014. 8. - C. 749 - 755. DOI: 10.7256/1999-2807.2014.8.12398.

11. Долгих И.П., Шебанов Д.В. Об оптимизации понятия "хищение" в российском законодательстве // NB: Вопросы права и политики. - 2014. - 5. - С. 23 - 37. DOI: 10.7256/2305-9699.2014.5.11933. URL: http://www.e-notabene.ru/ Ir/article_11933.html

12. Силаева Н.А. Предупреждение преступлений, посягающих на политическую систему России (некоторые специальные меры) // NB: Вопросы права и политики. - 2013. - 3. - С. 155 - 182. DOI: 10.7256/2305-9699.2013.3.542. URL: http://www.e-notabene.ru/lr/article_542.html 
13. Середина Н.А. Проблемы контроля (надзора) за деятельностью саморегулируемых организаций: административно-правовой аспект // Административное и муниципальное право. - 2012. - 12. - С. 79 - 83.

14. Дойников И.В. Второй этап кодификации российского законодательства: проблемы теории и практики государственного строительства // Административное и муниципальное право. - 2012. - 5. - С. 79 - 91.

\section{References (transliterated):}

1. Pan'shin D.L., Dresvyannikova E.A. Sroki i poryadok ispolneniya postanovlenii po delam ob administrativnykh pravonarusheniyakh o shtrafakh // Administrativnoe i munitsipal'noe pravo. - 2014.-№8. - 797 - 800.

2. Vinokurov A.Yu. Kontrol' za sootvetstviem raskhodov lits, zameshchayushchikh gosudarstvennye dolzhnosti, i inykh lits ikh dokhodam kak samostoyatel'naya funktsiya prokuratury // Administrativnoe i munitsipal'noe pravo.-2013.-2.C. 108-112. DOI: 10.7256/1999-2807.2013.02.2.

3. Ugolovnyi kodeks Rossiiskoi Federatsii ot 13 iyunya 1996 g. № 63-FZ (red. ot 21.07.2014 g.) (s izm. i dop. vstup. v silu 04.08.2014 g.) // Sobranie zakonodatel'stva RF. - 1996. - № 25. - Ct. 2954.

4. Postanovlenie Plenuma Verkhovnogo Suda Rossiiskoi Federatsii ot 09 iyulya 2013 g. № 24 «O sudebnoi praktike po delam o vzyatochnichestve i ob inykh korruptsionnykh prestupleniyakh». Ofitsial'nyi sait Verkhovnogo Suda Rossiiskoi Federatsii: http://www.supcourt.ru/second.php (Data obrashcheniya 15 oktyabrya 2014 g.).

5. Postanovlenie Plenuma Verkhovnogo Suda Rossiiskoi Federatsii ot 16 oktyabrya 2009 goda № 19 «0 sudebnoi praktike po delam o zloupotreblenii dolzhnostnymi polnomochiyami i o prevyshenii dolzhnostnykh polnomochii». Ofitsial'nyi sait Verkhovnogo Suda Rossiiskoi Federatsii: http://www.supcourt.ru/second.php (Data obrashcheniya 15 oktyabrya 2014 g.).

6. Kodeks Rossiiskoi Federatsii ob administrativnykh pravonarusheniyakh ot 30 dekabrya 2001 g. № 195-FZ (v red. Federal'nogo zakona ot 4 iyunya 2014 g. № 143-FZ) // Sobranie zakonodatel'stva Rossiiskoi Federatsii. 2002. № 1 (ch. I). St. 1

7. Chernogorov D.A. Istoki formirovaniya zakonodatel'stva i pravovoi doktriny o dolzhnostnykh litsakh // Administrativnoe i munitsipal'noe pravo.-2011.-11.-C. 88-91.

8. Chernogorov D.A. Publichnaya sluzhba i dolzhnostnoe litso // Administrativnoe i munitsipal'noe pravo.-2014.-8.-C. 749755. DOI: 10.7256/1999-2807.2014.8.12398.

9. Chepus A.V. Sovremennoe sostoyanie rossiiskogo zakonodatel'stva o parlamentskoi otvetstvennosti v RF // Pravo i politika. - 2013. - 12. - C. 1665 - 1671. DOI: 10.7256/1811-9018.2013.12.10214.

10. Chernogorov D.A. Publichnaya sluzhba i dolzhnostnoe litso // Administrativnoe i munitsipal'noe pravo. - 2014. - 8. C. 749 - 755. DOI: 10.7256/1999-2807.2014.8.12398.

11. Dolgikh I.P., Shebanov D.V. Ob optimizatsii ponyatiya "khishchenie" v rossiiskom zakonodatel'stve // NB: Voprosy prava i politiki. - 2014. - 5. - C. 23 - 37. DOI: 10.7256/2305-9699.2014.5.11933. URL: http://www.e-notabene.ru/lr/ article_11933.html

12. Silaeva N.A. Preduprezhdenie prestuplenii, posyagayushchikh na politicheskuyu sistemu Rossii (nekotorye spetsial'nye mery) // NB: Voprosy prava i politiki. - 2013. - 3. - C. 155 - 182. DOI: 10.7256/2305-9699.2013.3.542. URL: http:// www.e-notabene.ru/lr/article_542.html

13. Seredina N.A. Problemy kontrolya (nadzora) za deyatel'nost'yu samoreguliruemykh organizatsii: administrativnopravovoi aspekt // Administrativnoe i munitsipal'noe pravo. - 2012. - 12. - C. 79 - 83.

14. Doinikov I.V. Vtoroi etap kodifikatsii rossiiskogo zakonodatel'stva: problemy teorii i praktiki gosudarstvennogo stroitel'stva // Administrativnoe i munitsipal'noe pravo. - 2012. - 5. - C. 79 - 91. 